\title{
ANALISIS EKONOMI USAHATANI PADI DAN KELAYAKAN RUMAH TANGGA TANI DI DESA SAMBENG KULON KECAMATAN KEMBARAN KABUPATEN BANYUMAS
}

\author{
Chica Anditia Pratiwi, Diah Setyorini Gunawan, Istiqomah \\ Fakultas Ekonomi dan Bisnis Universitas Jenderal Soedirman \\ email: chicaanditiapratiwi@gmail.com
}

\begin{abstract}
This study aims to analyze the economic efficiency of rice farming, to measure the contribution of rice farming to total household income and to analyze the living standard of farm households. The study was conducted in Sambeng Kulon Village, Kembaran Sub-district, Banyumas District. Seventy-one farm households were selected by stratified random sampling. The analysis to measure the economic efficiency is $R / C$ ratio. The results indicated that 1) rice farming with an area of $\leq 0.5 \mathrm{Ha}$ had a smaller profit compared with respondents who had land area $>0.5 \mathrm{Ha}$,2) the average contribution of rice farming income to farm households with landholding of $\leq 0.5 \mathrm{Ha}$ is lower than that obtained by respondents with landholding of $>0.5 \mathrm{Ha}$,3) the average income earned by respondents from rice farming was sufficient to meet the average household consumption, and 4) of 71 respondents, 63 live below the decent living standard; after being added with nonfarm income, this figure decreased to 55 respondents. The implication of this research is that the respondents are expected to expand the landholding to increase income from rice farming or to earn additional nonfarm income so as to meet household consumption.
\end{abstract}

Keywords: rice farming, economic efficiency, consumption, decent living standard

\section{PENDAHULUAN}

Sektor pertanian berperan penting dalam pembangunan perekonomian nasional, terutama dalam menampung tenaga kerja di Indonesia. Data BPS pada Agustus 2016 menunjukkan bahwa sektor pertanian di Indonesia menyerap tenaga kerja sebesar 37.770.165 jiwa atau sebesar 31,89 persen. Sektor pertanian juga sangat berperan dalam pembangunan ekonomi nasional. PDB sektor pertanian tanaman pangan sebesar 270.977,4 milliar rupiah pada tahun 2011 nilai ini terus meningkat menjadi 393.371,7 miliar rupiah pada tahun 2015 (Badan Pusat Statistik, 2015).

Pembangunan pertanian perlu mendapat perhatian yang lebih baik, sehingga sektor pertanian dapat memiliki kemampuan untuk memberikan kesejahteraan hidup kepada petani. Hal ini dapat terjadi apabila produktivitas diperbesar, sehingga menghasilkan pendapatan yang lebih tinggi dan memungkinkan petani untuk menabung serta mengakumulasikan modal. Menurut Mosher (1987) pembangunan pertanian dapat berjalan dengan adanya lima syarat pokok yang harus ada dalam pembangunan pertanian, yaitu adanya pasar, teknologi yang senantiasa berkembang, tersedianya bahan-bahan dan alatalat produksi, adanya perangsang berproduksi bagi petani, dan tersedianya transportasi untuk menjangkau serta menyebarkan hasil produksi ke pasar.

Pertanian merupakan salah satu basis ekonomi kerakyatan di Indonesia. Pertanian pula yang menjadi penentu ketahanan pangan, yakni kondisi terpenuhinya pangan bagi negara sampai dengan perseorangan yang tercermin dari tersedianya pangan yang cukup (Undangundang Republik Indonesia Nomor 18 Tahun 2012 tentang Pangan). Dalam meningkatkan ketahanan pangan, tantangan besar saat ini adalah konsumsi masyarakat masih bertumpu pada beras, serta jumlah penduduk yang makin meningkat menyebabkan konsumsi beras untuk makanan pokok sehari-hari menjadi meningkat.

Jawa Tengah merupakan provinsi yang memiliki luas lahan pertanian terbesar kedua di Indonesia setelah Jawa Timur. Dikarenakan Jawa Tengah memiliki luas lahan sawah yang cukup luas, maka sektor pertanian juga merupakan sektor yang menyerap banyak tenaga kerja. 
Berdasarkan data BPS Provinsi Jawa Tengah dari hasil Survei Angkatan Kerja Nasional (SAKERNAS) pada tahun 2014 penduduk di Provinsi Jawa Tengah yang bekerja di sektor pertanian mencapai 5.173.986,atau sebanyak 32,11 persen.

Meskipun sektor pertanian merupakan sektor yang menyerap cukup banyak tenaga kerja, permasalahan dalam pertanian yang menghambat proses produksi masih cukup banyak diantaranya kerusakan lingkungan, perubahan iklim, infrastruktur, sarana prasarana, kepemilikan lahan, sistem perbenihan dan pembibitan nasional, akses petani terhadap permodalan, serta penyuluhan (Rencana Strategis Kementrian Pertanian, 2015). Dengan demikian petani di Indonesia dalam proses produksi masih belum maksimal, dan menyebabkan pendapatan yang diperoleh petani juga rendah.

Kesejahteraan petani dicerminkan pada Nilai Tukar Petani (NTP). Secara konsep NTP menyatakan tingkat kemampuan tukar atas barang-barang (produk) yang dihasilkan petani di pedesaan terhadap barang atau jasa yang dibutuhkan untuk konsumsi rumah tangga dan keperluan dalam proses produksi pertanian. Kecenderungan rendahnya nilai NTP juga dapat mengurangi minat petani untuk meningkatkan produktivitasnya secara optimal dalam jangka panjang dalam memproduksi padi (Hendayana, 2001). Nilai Tukar Petani di Jawa Tengah pada tahun 2015 dapat dilihat pada tabel berikut.
Berdasarkan data Tabel 1 pada Maret 2015 sampai dengan September 2015 NTP di bawah 100 yang artinya bahwa selama tahun 2015 petani lebih banyak mengalami defisit.

Selain itu, kesejahteraan rumah tangga tani dilihat dari terpenuhi tidaknya kebutuhan hidup petani yang diukur dengan standar Kebutuhan Hidup Layak (KHL). Kebutuhan Hidup Layak adalah standar kebutuhan yang harus dipenuhi oleh seorang pekerja atau buruh lajang untuk dapat hidup layak baik secara fisik, non fisik dan sosial, untuk kebutuhan 1 (satu) bulan. Kebutuhan Hidup Layak diatur dalam keputusan Menteri Tenaga Kerja dan Transmigrasi Nomor. 13 Tahun 2013 tentang Komponen dan Pelaksanaan Tahapan Pencapaian Kebutuhan Hidup Layak.

Salah satu kabupaten yang ada di Provinsi Jawa Tengah yaitu Kabupaten Banyumas. Berdasarkan data BPS Jawa tengah pada tahun 2015 luas panen di Kabupaten Banyumas mencapai 64.554 Hektar, dengan hasil produksi padi mencapai 364.135 ton.

Sebagian masyarakat di desa Sambeng Kulon Kecamatan Kembaran Kabupaten Banyumas bermata pencaharian sebagai petani karena daerah tersebut berada di dataran rendah, sehingga cocok untuk lahan pertanian terutama tanaman padi sawah. Tabel 2 menunjukkan bahwa produksi padi di Desa Sambeng Kulon selama 2011-2016 lebih banyak mengalami penurunan.

Tabel 1. Nilai Tukar Petani (NTP) per Sub Sektor Provinsi Jawa Tengah Januari - Desember 2015

\begin{tabular}{lrrrr}
\hline \multirow{2}{*}{ Bulan } & \multicolumn{4}{c}{ Sub Sektor } \\
\cline { 2 - 5 } & \multicolumn{1}{c}{ Padi } & Holtikultura & Peternakan & Perikanan \\
\hline Januari & 100,18 & 98,87 & 105,09 & 98,75 \\
Februari & 102,26 & 98,79 & 105,11 & 99,31 \\
Maret & 98,62 & 97,73 & 104,44 & 99,28 \\
April & 93,72 & 95,99 & 103,93 & 100,08 \\
Mei & 93,36 & 96,80 & 103,70 & 100,05 \\
Juni & 94,53 & 96,99 & 103,98 & 100,91 \\
Juli & 94,59 & 97,80 & 104,92 & 102,19 \\
Agustus & 96,49 & 97,20 & 106,27 & 102,19 \\
September & 99,87 & 97,68 & 107,77 & 103,39 \\
Oktober & 100,72 & 98,92 & 105,90 & 103,77 \\
November & 102,05 & 100,02 & 104,80 & 102,87 \\
Desember & 101,93 & 100,32 & 104,14 & 102,56 \\
\hline Sun
\end{tabular}


Tabel 2. Luas Panen, Produksi, dan Produktivitas Usahatani Padi di Desa Sambeng Kulon Tahun $2011-2016$

\begin{tabular}{cccc}
\hline Tahun & $\begin{array}{c}\text { Luas } \\
\text { Panen } \\
(\mathrm{Ha})\end{array}$ & $\begin{array}{c}\text { Produksi } \\
\text { (Ton) }\end{array}$ & $\begin{array}{c}\text { Produktivitas } \\
\text { (Ton/Ha) }\end{array}$ \\
\hline 2011 & 113,94 & 672,246 & 5,9 \\
2012 & 114,21 & 708,102 & 6,2 \\
2013 & 113,26 & 600,278 & 5,3 \\
2014 & 114,17 & 513,765 & 4,5 \\
2015 & 113,98 & 638,288 & 5,6 \\
2016 & 113,32 & 385,288 & 3,4 \\
\hline \multicolumn{4}{l}{ Sumber: Profil Desa Sambeng Kulon, 2016 }
\end{tabular}

Pada tahun 2016 produksi padi di Desa Sambeng Kulon menurun drastis karena serangan hama.

Berdasarkan survei awal pada 10 orang petani di Desa Sambeng Kulon pendapatan yang diperoleh petani tidak mencukupi untuk kebutuhan sehari-hari, sehingga menyebabkan petani mencari pekerjaan di luar sektor pertanian. Hal tersebut dapat dilihat pada tabel 3.

Berdasarkan Tabel 3 pendapatan petani dari sektor pertanian sangat rendah, rumah tangga tani berupaya menambah pendapatan di luar sektor pertanian. Rendahnya pendapatan dari sektor pertanian bisa saja membuat petani menjadi enggan untuk bekerja di sektor pertanian lagi sehingga akan menimbulkan permasalahan bagi ketahanan pangan. Berdasarkan uraian diatas maka disusun pertanyaan-pertanyaan penelitian sebagai berikut: a) seberapa menguntungkan usahatani padi di desa tersebut? b) seberapa besar kontibusi pendapatan yang diperoleh petani dari sektor pertanian terhadap pendapatan rumah tangga? c) apakah pendapatan rumah tangga dari sektor pertanian cukup untuk konsumsi rumah tangga tani? d) bagaimana kelayakan hidup rumah tangga tani di Desa Sambeng Kulon Kecamatan Kembaran Kabupaten Banyumas?

Manfaat dari penelitian ini adalah sebagai bahan masukan terhadap pemerintah daerah setempat untuk mengambil kebijakan dalam melaksanakan program-program yang berkaitan dengan pengembangan sektor pertanian dan sebagai masukan dan bahan informasi bagi petani agar lebih baik lagi dalam pengembangan dan pengelolaan usahatani padi, sehingga petani mendapatkan keuntungan dari usahatani padi.

\section{METODE PENELITIAN}

Penelitian ini merupakan jenis penelitian survei. Penelitian ini dilakukan di Desa Sambeng Kulon Kecamatan Kembaran Kabupaten Banyumas. Unit analisis adalah rumah tangga tani. Sumber data yang digunakan yaitu data primer dan data sekunder. Data primer diperoleh langsung dari responden melalui wawancara berdasarkan kuesioner. Sedangkan sekunder diperoleh dari monografi desa dan BPS.

Populasi penelitian ini terdiri dari 243 rumah tangga tani. Besarnya sampel diambil berdasarkan hasil perhitungan dengan mengunakan rumus Taro Yamane (1967), yaitu:

$$
n=\frac{N}{N\left(d^{2}\right)+1}
$$

Keterangan:

$\mathrm{n}=$ Ukuran sampel

$\mathrm{N}=$ Ukuran populasi

Tabel 3. Luas Lahan yang Dimiliki, Jumlah Anggota Keluarga dan Sumber Pendapatan Petani di Desa Sambeng Kulon

\begin{tabular}{ccccr}
\hline \multirow{2}{*}{$\begin{array}{c}\text { No } \\
\text { Responden }\end{array}$} & $\begin{array}{c}\text { Luas Lahan yang } \\
\text { Dimiliki }\left(\mathrm{M}^{2}\right)\end{array}$ & $\begin{array}{c}\text { Jumlah Anggota } \\
\text { Keluarga } \\
(\text { Jiwa })\end{array}$ & 2 & \multicolumn{2}{c}{ Sumber Pendapatan (Rp/bulan) } \\
\cline { 3 - 5 } 1 & 2.800 & 2 & 219.000 & $\begin{array}{c}\text { Non } \\
\text { Pertanian }\end{array}$ \\
2 & 2.800 & 3 & 220.000 & 180.000 \\
3 & 2.800 & 3 & 218.000 & 300.000 \\
4 & 3.500 & 4 & 510.000 & 400.000 \\
5 & 2.100 & 1 & 264.000 & 3.500 .000 \\
6 & 1.400 & 3 & 136.000 & 2.100 .000 \\
7 & 3.500 & 4 & 520.000 & 1.500 .000 \\
8 & 700 & 2 & 150.000 & 250.000 \\
9 & 1.400 & 4 & 145.000 & 400.000 \\
10 & 4.200 & 1.665 .000 & 200.000 \\
\hline Sumber: Wawancara padi & & 2.450 .000 \\
\hline
\end{tabular}

Sumber : Wawancara awal petani di Desa Sambeng Kulon 
$\mathrm{d}=$ Level signifikansi yang diinginkan (10\%).

$$
\begin{aligned}
& \boldsymbol{n}=\frac{\boldsymbol{N}}{\boldsymbol{N}\left(\boldsymbol{d}^{2}\right)+\mathbf{1}} \\
& n=\frac{243}{243\left(0,1^{2}\right)+1} \\
& n=70,85=71
\end{aligned}
$$

Karena populasi heterogen dalam pemilikan lahan, maka digunakan metode stratified random sampling yang dijelaskan pada Tabel 4. Pengacakan dilakukan dengan bantuan Microsoft Excel (RANDBETWEEN).

Tabel 4. Perhitungan sampel dengan stratified random sampling

\begin{tabular}{ccc}
\hline $\begin{array}{c}\text { Luas } \\
\text { Lahan } \\
(\mathrm{Ha})\end{array}$ & Populasi & Sampel \\
\hline $\mathbf{0 0 , 5}$ & 189 & $\frac{189}{243} X 71=\frac{189}{243} \times 71=$ \\
$55,22 \approx 55$ \\
& & $\frac{54}{243} X 71=\frac{54}{243} \times 71=$ \\
$>\mathbf{0 , 5}$ & 54 & $15,77 \approx 16$ \\
\hline
\end{tabular}

Penerimaan usahatani padi dalam penelitian ini menggunakan perhitungan penerimaan sebagai berikut (Soekartawi, 2002):

Keterangan:

$$
\mathrm{TR}=\mathrm{Q} \times \mathrm{P}
$$

$$
\begin{array}{ll}
\mathrm{TR} & =\text { Total Revenue } \\
\mathrm{Q} & =\text { Quantity } \\
\mathrm{P} & =\text { Price })
\end{array}
$$

a. Total biaya usahatani padi dihitung menggunakan rumus sebagai berikut (Soekartawi, 2002):

$$
\mathrm{TC}=\mathrm{TFC}+\mathrm{TVC}
$$

Keterangan:

$$
\begin{aligned}
& \text { TC } \quad=\text { Total Cost (Biaya total) } \\
& \text { TFC }=\text { Total Fixed Cost (Biaya tetap) } \\
& \text { TVC = Total Variable Cost (Biaya biaya } \\
& \text { tidak tetap) }
\end{aligned}
$$

b. Keuntungan usahatani padi dihitung dengan menggunakan rumus sebagai berikut (Soekartawi, 2002):

Keterangan:

$$
\boldsymbol{\pi}=\mathrm{TR}-\mathrm{TC}
$$

$\begin{array}{ll}\boldsymbol{\pi} & =\text { Profit } \\ \mathrm{TR} & =\text { Total Revenue } \\ \mathrm{TC} & =\text { Total Cost }\end{array}$

c. $\mathrm{R} / \mathrm{C}$

Analisis R/C ini digunakan untuk melihat perbandingan total penerimaan dengan total pengeluaran atau biaya usaha. Secara matematis, $\mathrm{R} / \mathrm{C}$ dapat dirumuskan sebagai berikut (Soekartawi, 2002):

Kriteria Pengujian :

$$
R / C \text { ratio }=\frac{T R}{T C} R / C \text { ratio }=\frac{T R}{T C}
$$

$\mathrm{R} / \mathrm{C}<1$ berarti usaha tani padi tidak menguntungkan atau tidak efisien.

$\mathrm{R} / \mathrm{C}=1$ berarti penghasilan usaha tani padi sama dengan biaya yang dikeluarkan untuk produksi.

$\mathrm{R} / \mathrm{C}>1$ berarti usaha tani padi menguntungkan atau usahatani padi sudah efisien.

Untuk mengetahui ada atau tidaknya perbedaan antara dua kelompok data, digunakan pengujian statistic hipotesis perbedaan dua ratarata dengan tingkat kepercayaan $95 \%$ atau $\alpha$ $=0,05$ (Usman dan Akbar, 2009). Besarnya sampel (n) yang digunakan dalam hipotesis ini dapat ditentukan uji distribusi apa yang cocok digunakan. Apabila sampel lebih atau sama dengan 30 sehingga pengujian yang cocok menggunakan distribusi Z. Nilai Z untuk beda dua rata-rata dan tidak diketahui simpangan baku populasinya dapat ditentukan dengan rumus sebagai berikut (Algifari, 2003).

$$
\begin{aligned}
& Z=\frac{X_{1}-X_{2}}{S_{X_{1}}-S_{X_{2}}} Z=\frac{X_{1}-X_{2}}{S_{X_{1}}-S_{X_{2}}} \quad \text { dengan } \\
& S_{X_{1}}-S_{X_{2}}=\sqrt{\frac{S_{1}^{2}}{n_{1}}+\frac{S_{2}^{2}}{n_{2}}}
\end{aligned}
$$

Keterangan :

Z : Z statistik

$\mathrm{X}_{1} \quad$ : Rata-rata sampel 1

$\mathrm{X}_{2}$ : Rata-rata sampel 2

$\mathrm{S} \quad$ : Simpangan baku sampel

$\mathrm{n}_{1} \quad$ : Jumlah sampel 1

$\mathrm{n}_{2} \quad$ : Jumlah sampel 2

Karena simpangan baku tidak diketahui maka pengujian hipotesis perbedaan dua ratarata dapat menggunakan uji t. sehingga hipotesis statistik dapat disimpulkan sebagai berikut.

Hipotesis Statistik :

$\mathrm{H}_{0} \quad$ : tidak terdapat perbedaan keuntungan yang diperoleh responden yang memiliki luas lahan $\leq 0,5 \mathrm{Ha}$ dan responden yang memiliki luas lahan $>0,5 \mathrm{Ha}$.

$\mathrm{Ha}$ : terdapat perbedaan keuntungan yang diperoleh responden yang memiliki luas lahan $\leq 0,5 \mathrm{Ha}$ dan responden yang memiliki luas lahan $>0,5 \mathrm{Ha}$. 
Kriteria pengujian hipotesis statistik :

1. Jika nilai $t$ hitung negatif : $t$ hitung $<$ dari $t$ tabel yaitu $=1,99$ maka $\mathrm{H}_{0}$ ditolak dan $\mathrm{H}_{\mathrm{a}}$ diterima.

2. Jika nilai $t$ hitung positif : $t$ hitung $>$ dari $t$ tabel yaitu $=1,99$ maka $\mathrm{H}_{0}$ ditolak dan $\mathrm{H}_{\mathrm{a}}$ diterima.

\section{Analisis Kontribusi Pendapatan Usahatani} Padi terhadap Pendapatan Rumah Tangga

Untuk mengetahui kontribusi usaha tani padi terhadap pendapatan total rumah tangga digunakan rumus persentase sebagai berikut (Mulato, Widyotomo, dan Suharyanto, 2004)

Kontribusi (\%) $=$ Pendapatan Usahatani Padi X 100\% Pendapatan Total

\section{Analisis Pemenuhan Kebutuhan Hidup Layak (KHL)}

Pemenuhan standar KHL menurut BPS Jawa Tengah pada tahun 2016 di Kabupaten Banyumas adalah sebesar Rp1.336.821,00. Kelayakan Hidup Rumah Tangga Tani digunakan rumus sebagai berikut.

KHL $=\underline{\text { Pendapatan Usahatani Padi }}$ Kebutuhan Hidup Layak

Kriteria pengujian :

a. Apabila $\mathrm{KHL}<1$, maka pendapatan rumah tangga tani dikatakan tidak mencukupi kebutuhan hidup rumah tangga tani (tidak sejahtera).

b. Apabila $\mathrm{KHL} \geq 1$, maka pendapatan rumah tangga tani mencukupi kebutuhan hidup rumah tangga tani (sejahtera).

\section{HASIL DAN PEMBAHASAN}

\section{A. Gambaran Umum Responden}

1. Usia Responden

Usia sangat berpengaruh terhadap aktivitas petani dalam melakukan usahatani. Usia responden dapat dilihat pada tabel berikut.

Tabel 5. Usia Responden

\begin{tabular}{lccc}
\hline No & Usia (Tahun) & $\begin{array}{c}\text { Jumlah } \\
\text { (Orang) }\end{array}$ & $\begin{array}{c}\text { Persentase } \\
(\%)\end{array}$ \\
\hline 1 & $35-45$ & 12 & 16,90 \\
2 & $>45-55$ & 23 & 32,39 \\
3 & $>55-65$ & 20 & 28,17 \\
4 & $>65-75$ & 16 & 22,54 \\
\hline & Jumlah & 71 & 100,00 \\
\hline
\end{tabular}

Sumber: Data Primer diolah, 2017
Dapat dilihat pada Tabel 5 bahwa sebagian besar responden berada pada usia tua yaitu $>45-$ 55 tahun. Rendahnya pendapatan yang diperoleh dalam usahatani padi menjadi salah satu alasan mengapa sebagian besar penduduk yang masih muda lebih tertarik bekerja di luar sektor pertanian seperti karyawan pabrik, karyawan toko, dan sebagainya yang dapat memberikan pendapatan lebih tinggi.

\section{Tingkat Pendidikan}

Tingkat pendidikan merupakan salah satu unsur yang berpengaruh terhadap proses pengambilan keputusan petani. Semakin tinggi tingkat pendidikan petani maka semakin mudah pula petani menerima teknologi baru yang dapat menunjang keberhasilan usahataninya.

Tabel 6. Tingkat Pendidikan Responden

\begin{tabular}{clcc}
\hline No & \multicolumn{1}{c}{$\begin{array}{c}\text { Tingkat } \\
\text { Pendidikan }\end{array}$} & Jumlah & (\%) \\
\hline 1 & Tidak Tamat SD & 12 & 16,90 \\
2 & SD & 30 & 42,25 \\
3 & SMP/Sederajat & 18 & 25,35 \\
4 & SMA/Sederajat & 8 & 11,27 \\
5 & Akademi (D1-D3) & - & - \\
6 & Sarjana & 3 & 4,23 \\
\hline & Jumlah & 71 & 100,00 \\
\hline
\end{tabular}

Sumber: Data Primer diolah, 2017

Tabel 6 menunjukkan bahwa responden pada umumnya hanya dapat menempuh pendidikan formal sampai jenjang pendidikan Sekolah Dasar (SD).

3. Jumlah Tanggungan Keluarga

Jumlah tanggungan keluarga sangat berpengaruh terhadap tingkat kesejahteraan petani. Semakin banyak tanggungan keluarga petani, maka semakin besar pula biaya hidup yang ditanggung oleh petani tersebut.

Tabel 7. Jumlah Tanggungan Keluarga Responden

\begin{tabular}{ccrr}
\hline No & $\begin{array}{c}\text { Jumlah } \\
\text { Tanggungan } \\
\text { Keluarga (Orang) }\end{array}$ & $\begin{array}{c}\text { Jumlah } \\
\text { (Orang) }\end{array}$ & \multicolumn{1}{c}{$\%$} \\
\hline 1 & 1 & 2 & 2,82 \\
2 & 2 & 30 & 42,25 \\
3 & 3 & 20 & 28,17 \\
4 & 4 & 15 & 21,13 \\
5 & 5 & 4 & 5,63 \\
\hline & Jumlah & 71 & 100,00
\end{tabular}

Sumber: Data Primer diolah, 2017 
Tabel 7 menunjukkan bahwa dari 71 responden, sebagian besar memiliki tanggungan keluarga sebanyak 2 orang.

\section{Luas Lahan}

Lahan sangat penting, karena lahan merupakan tempat yang digunakan petani untuk melakukan produksi. Semakin luas lahan, maka hasil produksi akan lebih banyak. Dalam penelitian ini luas lahan didefinisikan sebagai luas lahan garapan yang terdiri dari luas lahan yang dimiliki dan luas lahan yang disewa.

Tabel 8. Luas Lahan yang Dimiliki Responden

\begin{tabular}{cccc}
\hline No & $\begin{array}{c}\text { Luas } \\
\text { Lahan (Ha) }\end{array}$ & $\begin{array}{c}\text { Jumlah } \\
\text { (Orang) }\end{array}$ & Persentase (\%) \\
\hline 1. & $\leq 0,5$ & 55 & 77,46 \\
2. & $>0,5$ & 16 & 22,56 \\
\hline & Jumlah & 71 & 100,00
\end{tabular}

Sumber: Data Primer diolah, 2017

Tabel 8 menunjukkan bahwa sebagian besar petani di Desa Sambeng Kulon hanya memiliki luas lahan $\leq 0,5 \mathrm{Ha}$. Hal tersebut dikarenakan kurangnya modal yang dimiliki responden untuk menyewa atau membeli lahan persawahan. Luas lahan paling sempit yang dimiliki responden di Desa Sambeng Kulon yaitu sebesar $0,02 \mathrm{Ha}$, sedangkan yang paling luas yaitu sebesar 1,28 Ha.

\section{B. Analisis Data}

1. Analisis Pendapatan

a. Pendapatan Usahatani Padi

Rata-rata produksi padi dan pendapatan dari usahatani padi di Desa Sambeng Kulon dapat dilihat pada tabel 9 yang menunjukkan bahwa responden yang memiliki luas lahan $\leq 0,5 \mathrm{Ha}$ menghasilkan rata-rata produksi sebanyak 11,06 kwintal dengan rata-rata pendapatan sebesar Rp4.434.455,00 dalam satu kali musim tanam. Sedangkan responden yang memiliki luas lahan $>0,5$ Ha menghasilkan ratarata produksi sebanyak 31,37 kwintal dengan rata-rata pendapatan yang diperoleh sebesar Rp12.550.000,00 dalam satu kali musim tanam.

b. Biaya Usahatani Padi

1) Biaya Tetap

a. Biaya Pajak dan Sewa Lahan

Dalam penelitian ini semua responden di Desa Sambeng Kulon memiliki lahan sendiri, tetapi ada pula responden yang sudah memiliki lahan sendiri tetapi masih menyewa lahan. Hal tersebut dapat dilihat pada tabel 10 yang menunjukkan bahwa rata-rata biaya pajak yang dibayar oleh responden di Desa Sambeng Kulon yang memiliki luas lahan sendiri tanpa menyewa dengan luas lahan $\leq 0,5$ Ha sebesar Rp18.538,00 sedangkan responden yang memiliki lahan sendiri dan memiliki lahan sewaan dengan luas lahan $\leq 0,5 \mathrm{Ha}$ akan membayar biaya pajak dan biaya sewa lahan sebesar Rp478.315,00 per 4 bulan. Responden yang memiliki luas lahan sendiri $>0,5 \mathrm{Ha}$ tanpa menyewa membayar rata-rata biaya pajak sebesar Rp61.031,00 per 4 bulan, sedangkan responden yang memiliki lahan sendiri dan lahan sewaan dengan luas lahan $>0,5$ membayar biaya pajak dan biaya sewa per 4 bulan rata-rata sebesar Rp1.506.583,00. b. Biaya Penyusutan

Alat-alat yang digunakan dalam usahatani padi adalah cangkul, pisau, dan alat

Tabel 9. Rata-rata Produksi Padi dan Pendapatan yang Diperoleh Responden Berdasarkan Luas Lahan

\begin{tabular}{lccrrr} 
No & $\begin{array}{c}\text { Luas Lahan } \\
(\mathrm{Ha})\end{array}$ & $\begin{array}{c}\text { Banyaknya } \\
\text { Responden (Orang) }\end{array}$ & $\begin{array}{c}\text { Rata-rata Jumlah } \\
\text { Produksi (Kw) }\end{array}$ & $\begin{array}{c}\text { Harga Rata-rata Per } \\
\text { Kwintal (Rp) }\end{array}$ & $\begin{array}{c}\text { Rata-Rata Pendapatan } \\
\text { (Rp) }\end{array}$ \\
\hline 1. & $\leq 0,5$ & 55 & 11,06 & 401.182 & 4.434 .455 \\
2. & $>0,5$ & 16 & 31,37 & 400.000 & 12.550 .000 \\
\hline
\end{tabular}

Sumber: Data Primer diolah, 2017

Tabel 10. Rata-rata Biaya Pajak dan Biaya Sewa Per 4 bulan Berdasarkan Luas Lahan

\begin{tabular}{rcrrrr}
\hline No & $\begin{array}{c}\text { Luas Lahan } \\
(\mathrm{Ha})\end{array}$ & $\begin{array}{c}\text { Banyaknya } \\
\text { Responden (Orang) }\end{array}$ & $\begin{array}{c}\text { Rata-rata Biaya Pajak Per } \\
\text { 4 bulan (Rp) }\end{array}$ & $\begin{array}{c}\text { Rata-rata Biaya Sewa } \\
\text { Per 4 bulan (Rp) }\end{array}$ & Total (Rp) \\
\hline 1 & $\leq 0,5$ & 48 & 18.538 & - & 18.538 \\
2 & $\leq 0,5$ & 7 & 9.267 & 469.048 & 478.315 \\
3 & $>0,5$ & 14 & 61.031 & - & 61.031 \\
4 & $>0,5$ & 2 & 73.250 & 1.433 .333 & 1.506 .583 \\
\hline
\end{tabular}


penyemprot hama. Untuk persiapan lahan, responden menyewa traktor dan tenaga kerjanya.

Tabel 11. Rata-rata Biaya Penyusutan Alat-alat Pertanian Usahatani Padi

\begin{tabular}{|c|c|c|c|}
\hline \multirow[b]{2}{*}{ No } & \multirow[b]{2}{*}{ Nama Alat } & \multicolumn{2}{|c|}{ Rata-rata per 4 bulan (Rp) } \\
\hline & & $\begin{array}{c}\text { Luas Lahan } \\
\leq 0,5 \mathrm{Ha}\end{array}$ & $\begin{array}{c}\text { Luas Lahan } \\
>0,5 \mathrm{Ha}\end{array}$ \\
\hline 1. & Cangkul & 11.467 & 12.925 \\
\hline 2. & Pisau & 1.409 & 729 \\
\hline 3. & Arit & 7.839 & 7.196 \\
\hline 4. & $\begin{array}{l}\text { Penyemprot } \\
\text { Hama }\end{array}$ & 14.310 & 16.024 \\
\hline & Jumlah & 35.080 & 36.875 \\
\hline
\end{tabular}

Sumber: Data Primer diolah, 2017

Tabel 11 menunjukkan bahwa biaya penyusutan alat-alat pertanian antara responden yang memiliki luas lahan $\leq 0,5 \mathrm{Ha}$ dan $>0,5 \mathrm{Ha}$ tidak jauh berbeda, karena para pekerja umumnya membawa peralatan sendiri.

2) Biaya Variabel

a. Upah Tenaga Kerja

Tenaga kerja yang digunakan oleh responden sebagian besar berasal dari luar keluarga meskipun ada tenaga kerja dalam keluarga seperti anak yang sudah menikah yang membantu dan tidak dibayar oleh responden tersebut. Dalam penelitian ini tenaga kerja dalam keluarga juga diperhitungkan upahnya. Proses produksi usahatani padi terdiri dari persemaian, persiapan lahan, penanaman, pemupukan, penyiangan, penyemprotan, dan pemanenan. Rata-rata biaya tenaga kerja yang dikeluarkan responden di Desa Sambeng Kulon dalam satu kali musim tanam dapat dilihat pada tabel berikut.

Tabel 12. Rata-rata Biaya Tenaga Kerja Usahatani Padi Berdasarkan Luas Lahan (Dalam Rupiah)

\begin{tabular}{llrr}
\hline \multirow{2}{*}{ No } & \multirow{2}{*}{ Kegiatan } & \multicolumn{2}{c}{ Rata-rataBiaya Tenaga } \\
\cline { 3 - 4 } & & $\begin{array}{c}\text { Luaslahan } \\
\leq 0,5\end{array}$ & \multicolumn{2}{c}{ Lahan $_{0,5}$} \\
\hline 1. & Persemaian & 55.236 & 184.750 \\
2. & Persiapan Lahan & 133.818 & 256.250 \\
3. & Penanaman & 184.000 & 621.250 \\
4. & Pemupukan & 51.509 & 130.313 \\
5. & Penyiangan & 79.800 & 176.563 \\
6. & Penyemprotan & 51.273 & 131.563 \\
7. & Pemanenan & 194.818 & 366.563 \\
\hline & Jumlah & 750.454 & 1.831 .250 \\
\hline
\end{tabular}

Sumber: Data Primer diolah, 2017

\section{b. Biaya Benih}

Sebagian besar responden di Desa Sambeng Kulon sudah menggunakan benih unggul dan untuk harga benihnya responden mendapatkan bantuan dari pemerintah berupa subsidi harga. Akan tetapi responden menambahkan benih yang digunakan dari hasil panen sebelumnya. Biaya benih yang digunakan responden dapat dilihat pada tabel berikut.

Tabel 13. Rata-rata Biaya Benih Padi yang Dikeluarkan oleh Responden di Desa Sambeng Kulon Kecamatan Kembaran Kabupaten Banyumas

\begin{tabular}{ccccc}
\hline $\begin{array}{c}\text { Luas } \\
\text { Lahan } \\
(\mathrm{Ha})\end{array}$ & $\begin{array}{c}\text { Jumlah } \\
\text { Responden } \\
\text { (Orang) }\end{array}$ & $\begin{array}{c}\text { Rata-rata } \\
\text { Jumlah } \\
\text { Benih yang } \\
\text { Digunakan } \\
(\mathrm{Kg})\end{array}$ & $\begin{array}{c}\text { Rata- } \\
\text { Rata } \\
\text { Harga } \\
\text { Benih } \\
\text { per Kg } \\
(\mathrm{Rp})\end{array}$ & $\begin{array}{c}\text { Rata- } \\
\text { rata } \\
\text { Biaya } \\
\text { Benih } \\
(\mathrm{Rp})\end{array}$ \\
\hline$\leq 0,5$ & 55 & 14 & 10.415 & 145.973 \\
$>0,5$ & 16 & 38 & 10.381 & 389.869 \\
\hline
\end{tabular}

Sumber: Data Primer diolah, 2017

Tabel 13 menunjukkan bahwa rata-rata biaya benih padi yang dikeluarkan oleh responden tergantung pada luas lahan, semakin luas lahan yang dimiliki responden maka semakin besar biaya benih yang dikeluarkan.

c. Pupuk

Pemupukan disesuaikan dengan keadaan tanah agar pertumbuhan tanaman dapat berjalan baik. Pupuk yang digunakan oleh responden di Desa Sambeng Kulon umumnya yaitu pupuk urea dan ponska. Biaya yang dikeluarkan oleh responden di Desa Sambeng Kulon dapat dilihat pada tabel berikut.

Tabel 14. Rata-rata Biaya Pupuk yang Dikeluarkan oleh Responden di Desa Sambeng Kulon Kecamatan Kembaran Kabupaten Banyumas

\begin{tabular}{cccccc}
\hline & \multirow{2}{*}{ Nuas } & Jumlah & \multicolumn{2}{c}{ Jenis pupuk } & Rata-rata \\
\cline { 4 - 5 } No & $\begin{array}{c}\text { Lahan } \\
\text { Riaya }\end{array}$ & $\begin{array}{c}\text { Responden } \\
\text { (Ha) }\end{array}$ & $\begin{array}{c}\text { Urea } \\
\text { (Orang) }\end{array}$ & $\begin{array}{c}\text { Ponska } \\
\text { (Rp) }\end{array}$ & $\begin{array}{c}\text { (Rp) } \\
\text { pupuk } \\
\text { (Rp) }\end{array}$ \\
1. & $\leq 0,5$ & 55 & 101.160 & 114.165 & 215.325 \\
2. & $>0,5$ & 16 & 304.781 & 348.956 & 653.738 \\
\hline
\end{tabular}

Sumber: Data Primer diolah, 2017

Tabel 14 menunjukkan bahwa rata-rata biaya pupuk yang dikeluarkan oleh responden tergantung pada luas lahan, semakin luas lahan yang dimiliki responden maka semakin besar biaya pupuk yang dikeluarkan. 


\section{d. Biaya Pestisida}

Responden di Desa Sambeng Kulon umumnya menggunakan pestida untuk mengatasi hama dan penyakit yang menyerang tanaman padi. Responden menggunakan insektisida dan herbisida. Insektisida merupakan pestisida untuk memberantas serangga, seperti belalang, ulat dan sebagainya. Sedangkan pestisida jenis herbisida untuk mencegah dan mematikan gulma atau tumbuhan pengganggu. Biaya pestisida yang dikeluarkan oleh responden dapat dilihat pada tabel berikut.

Tabel 15. Rata-rata Biaya Pestisida yang Dikeluarkan oleh Responden Berdasarkan Luas Lahan di Desa Sambeng Kulon Kecamatan Kembaran Kabupaten Banyumas

\begin{tabular}{|c|c|c|c|c|}
\hline \multirow[b]{2}{*}{ No } & \multirow{2}{*}{$\begin{array}{c}\text { Luas } \\
\text { Lahan } \\
\text { (Ha) }\end{array}$} & \multicolumn{2}{|c|}{ Jenis Pestisida } & \multirow{2}{*}{$\begin{array}{l}\text { Rata-rata } \\
\text { Biaya } \\
\text { Pestisida } \\
\text { (Rp) }\end{array}$} \\
\hline & & $\begin{array}{l}\text { Herbisida } \\
\text { (Rp) }\end{array}$ & $\begin{array}{l}\text { Insektisida } \\
\text { (Rp) }\end{array}$ & \\
\hline 1. & $\leq 0,5$ & 27.9 & 44.2 & 72.145 \\
\hline 2. & $>0,5$ & 70.438 & 125.313 & 195.75 \\
\hline
\end{tabular}

Tabel 15 menunjukkan bahwa rata-rata biaya pestisida yang dikeluarkan oleh responden tergantung juga pada luas lahan yang digunakan.

Dari penjelasan input-input yang dikeluarkan oleh responden di Desa Sambeng Kulon untuk usahatani padi, maka diperoleh rata-rata biaya tetap dan biaya variabel yang dikeluarkan oleh responden sebagaimana ditampilkan pada tabel berikut.

Tabel 16. Rata-rata Biaya yang Dikeluarkan oleh Responden Berdasarkan Luas Lahan

\begin{tabular}{llrc}
\hline \multirow{2}{*}{ No } & \multirow{2}{*}{ Jenis Biaya } & \multicolumn{2}{c}{ Luas Lahan $(\mathrm{Ha})$} \\
\cline { 3 - 4 } & & \multicolumn{1}{c}{$\leq 0,5$} & $>0,5$ \\
\hline 1. & Biaya Tetap & 531.978 & 1.604 .489 \\
2. & Biaya Variabel & 1.183 .897 & 3.070 .607 \\
\hline & Total Biaya & 1.715 .875 & 4.675 .096 \\
\hline
\end{tabular}

Sumber: Data Primer diolah, 2017

Berdasarkan Tabel 16 dapat dilihat bahwa ratarata biaya yang dikeluarkan oleh responden lebih besar untuk biaya variabel.

\section{c. Keuntungan Usahatani Padi}

Keuntungan usahatani padi merupakan selisih antara total pendapatan yang diperoleh dengan total biaya yang dikeluarkan selama proses produksi. Rata-rata keuntungan usahatani padi yang diperoleh responden di Desa Sambeng Kulon dapat dilihat pada tabel berikut.

Tabel 17. Rata-rata keuntungan yang Diperoleh Responden Berdasarkan Luas Lahan

\begin{tabular}{llcc}
\hline \multirow{2}{*}{ No } & \multicolumn{1}{c}{ Uraian } & $\begin{array}{c}\text { Luas } \\
\text { Lahan } \leq \\
0,5\end{array}$ & $\begin{array}{c}\text { Luas } \\
\text { Lahan }>0,5\end{array}$ \\
\hline 1. & $\begin{array}{l}\text { Rata-rata } \\
\text { Pendapatan }\end{array}$ & 4.434 .455 & 12.550 .000 \\
2. & Rata-rata Biaya & 1.715 .875 & 4.675 .096 \\
\hline & $\begin{array}{l}\text { Rata-rata } \\
\text { Keuntungan }\end{array}$ & 2.718 .580 & 7.892 .904 \\
\hline
\end{tabular}

Sumber: Data Primer diolah, 2017

Keuntungan yang diperoleh tiap responden dapat dilihat pada tabel berikut.

Tabel 18. Keuntungan per Responden dari Usahatani Padi di Desa Sambeng Kulon Kecamatan Kembaran Kabupaten Banyumas

\begin{tabular}{|c|c|c|c|}
\hline \multirow[b]{2}{*}{ No } & \multirow[b]{2}{*}{$\begin{array}{c}\text { Keuntungan (Ribuan } \\
\text { Rp) }\end{array}$} & \multicolumn{2}{|c|}{ Jumlah (Orang) } \\
\hline & & $\begin{array}{c}\text { Luas } \\
\text { Lahan } \leq \\
0,5\end{array}$ & $\begin{array}{l}\text { Luas } \\
\text { Lahan } \\
>0,5\end{array}$ \\
\hline 1. & $400-1.400$ & 14 & - \\
\hline 2. & $>1.400-2.400$ & 11 & - \\
\hline 3. & $>2.400-3.400$ & 6 & - \\
\hline 4. & $>3.400-4.400$ & 10 & - \\
\hline 5. & $>4.400-5.400$ & 10 & - \\
\hline 6. & $>5.400-6.400$ & 4 & 1 \\
\hline 7. & $>6.400-7.400$ & - & 1 \\
\hline 8. & $>7.400-8.400$ & - & 5 \\
\hline 9. & $>8.400-9.400$ & - & 5 \\
\hline 10. & $>9.400-10.400$ & - & 2 \\
\hline 11. & $>10.400-11.400$ & - & 1 \\
\hline 12. & $>11.400-12.400$ & - & - \\
\hline 13. & $>12.400-13.400$ & - & 1 \\
\hline & Jumlah & 55 & 16 \\
\hline
\end{tabular}

Tabel 18 menunjukkan bahwa responden yang memiliki luas lahan $\leq 0,5 \mathrm{Ha}$ memperoleh keuntungan lebih kecil apabila dibandingkan dengan responden yang memiliki luas lahan $>0,5 \mathrm{Ha}$.

d. $\mathrm{R} / \mathrm{C}$

Keuntungan usahatani dapat dianalisis menggunakan $\mathrm{R} / \mathrm{C}$ ratio. $\mathrm{R} / \mathrm{C}$ ratio ini digunakan untuk melihat kelayakan usahatani. Analisis 
efisiensi ekonomi usahatani di Desa Sambeng Kulon dapat dilihat pada tabel berikut.

Tabel 19. Rata-rata Efisiensi Ekonomi Usahatani Padi

\begin{tabular}{|c|c|c|c|}
\hline \multirow[b]{2}{*}{ No } & \multirow[b]{2}{*}{ Uraian } & \multicolumn{2}{|c|}{ Rata-rata (Rp) } \\
\hline & & $\begin{array}{c}\text { Luas Lahan } \\
\leq 0,5 \mathrm{Ha} \\
\end{array}$ & $\begin{array}{c}\text { Luas Lahan } \\
>0,5 \mathrm{Ha}\end{array}$ \\
\hline 1. & $\begin{array}{l}\text { Penerimaan } \\
\text { Total }\end{array}$ & 4.434 .455 & 12.550 .000 \\
\hline 2. & Biaya Total & 1.715 .875 & 4.675 .096 \\
\hline & R/C Ratio & 2,58 & 2,68 \\
\hline
\end{tabular}

Berdasarkan Tabel 19 dapat dilihat bahwa nilai $\mathrm{R} / \mathrm{C}$ dari responden yang memiliki luas lahan $>0,5$ lebih tinggi dibandingkan dengan nilai $\mathrm{R} / \mathrm{C}$ ratio dari responden yang memiliki luas lahan $\leq 0,5 \mathrm{Ha}$. Dari hasil pengujian statistik hipotesis perbedaan dua rata-rata dengan tingkat kepercayaan $95 \%$ atau $\alpha=0,05$ diketahui bahwa nilai t hitung adalah -11,99 lebih kecil dari t tabel = 1,99 artinya bahwa $\mathrm{H}_{0}$ ditolak dan $\mathrm{H}_{\mathrm{a}}$ diterima. Dengan demikian terdapat perbedaan besarnya keuntungan yang diperoleh dari responden yang memiliki luas lahan $\leq 0,5$ Hektar dan $>0,5$ Hektar.

Hasil penelitian ini sesuai dengan penelitian Pratama (2014) yang menunjukkan bahwa nilai $\mathrm{R} / \mathrm{C}$ ratio yang diperoleh di Desa Sidondo $>1$, yang artinya bahwa usahatani padi menguntungkan dan layak untuk diusahakan.

2. Analisis Kontribusi Pendapatan Usahatani Padi terhadap Pendapatan Rumah Tangga

Kontribusi pendapatan usahatani padi dapat dilihat pada tabel berikut.

Tabel 20. Rata-rata Kontribusi Pendapatan dari Usahatani Padi terhadap Pendapatan Rata-rata Rumah Tangga Tani

\begin{tabular}{cccc}
\hline No & $\begin{array}{c}\text { Luas } \\
\text { Lahan (Ha) }\end{array}$ & $\begin{array}{c}\text { Jumlah } \\
\text { Responden } \\
(\text { Orang) }\end{array}$ & $\begin{array}{c}\text { Rata-rata } \\
\text { Kontribusi } \\
(\%)\end{array}$ \\
\hline 1. & $\leq 0,5$ & 55 & 54,96 \\
2. & $>0,5$ & 16 & 77,43 \\
\hline
\end{tabular}

Sumber: Data Primer diolah, 2017

Tabel 20 menunjukkan bahwa kontribusi pendapatan usahatani padi dari responden yang memiliki luas lahan $>0,5$ hektar lebih besar dibandingkan dengan responden yang memiliki luas lahan $\leq 0,5$ hektar.
Dari hasil pengujian statistik hipotesis perbedaan dua rata-rata dengan tingkat kepercayaan $95 \%$ atau $\alpha=0,05$ diketahui bahwa nilai $\mathrm{t}$ hitung adalah $-2,081<\mathrm{t}$ tabel $=1,99$ yang artinya bahwa $\mathrm{H}_{0}$ ditolak dan $\mathrm{H}_{\mathrm{a}}$ diterima. Dengan demikian terdapat perbedaan besarnya kontribusi pendapatan usahatani dari responden yang memiliki luas $\leq 0,5$ hektar dan petani yang memiliki luas lahan $>0,5$ hektar.

Hasil penelitian ini berbeda dengan Pancawati (2012) yang menemukan bahwa pendapatan dari buruh tani di Desa Penancangan masih berada di bawah 50 persen yaitu hanya sebesar 31,30 persen, dan penelitian Anton dan Marhawati (2016) yang mengatakan bahwa kontribusi pendapatan usahatani padi sawah terhadap usahatani keluarga mencapai 48,18 persen yang artinya kontribusi pendapatan dari usahatani padi masih rendah.

3. Analisis Konsumsi Rumah Tangga Tani

Secara umum besaran konsumsi yang dikeluarkan oleh rumah tangga tani terdapat konsumsi rutin seperti kebutuhan pangan, listrik, transportasi, kebutuhan non pangan, uang saku anak, arisan, dan hiburan. Selain itu terdapat pula konsumsi yang dilakukan oleh responden tidak secara rutin seperti dana sosial, pendidikan, kesehatan dan liburan. Besarnya konsumsi rumah tangga tani dapat dilihat pada tabel berikut.

Tabel 21. Rata-rata Konsumsi Bulanan Rumah Tangga Tani di Desa Sambeng Kulon Kecamatan Kembaran Kabupaten Banyumas

\begin{tabular}{clr}
\hline No & \multicolumn{1}{c}{ Uraian } & \multicolumn{1}{c}{ Jumlah (Rp) } \\
\hline 1. & $\begin{array}{l}\text { Rata-rata Konsumsi } \\
\text { Rutin Bulanan }\end{array}$ & 1.328 .324 \\
2. & $\begin{array}{l}\text { Konsumsi Tahunan } \\
\text { dirata-rata per Bulan }\end{array}$ & 51.117 \\
\hline & $\begin{array}{l}\text { Rata-rata Konsumsi } \\
\text { Bulanan }\end{array}$ & 1.379 .441 \\
\hline
\end{tabular}

Sumber: Data Primer diolah, 2017

Tabel 21 menunjukkan bahwa biaya yang dikeluarkan untuk konsumsi rumah tangga tani yaitu sebesar Rp1.379.441,00 pengeluaran untuk konsumsi tersebut lebih kecil dari rata-rata pendapatan yang diperoleh dari usahatani padi yaitu sebesar Rp1.624.961,00 artinya pendapatan dari usahatani padi dapat memenuhi kebutuhan rumah tangga tani di Desa Sambeng Kulon, meskipun rata-rata pendapatan dari usahatani padi sudah mencukupi untuk konsumsi. Tetapi 
masih terdapat responden yang belum bisa mencapai memenuhi konsumsi rumah tangga, sehingga responden mencari pendapatan di luar usahatani padi. Tetapi dengan adanya tambahan pendapatan dari luar usahatani padi, total pendapatan yang diperoleh responden sebesar Rp2.218.784,00 dengan biaya yang dikeluarkan untuk konsumsi rumah tangga tani yaitu sebesar Rp1.379.441 artinya pendapatan total rumah tangga tani dapat memenuhi kebutuhan rumah tangga tani. Jumlah konsumsi bulanan responden yang terpenuhi dan tidak terpenuhi dari usahatani padi dapat dilihat pada tabel berikut.

Tabel 22. Konsumsi Bulanan per Rumah Tangga Tani yang Terpenuhi dan Tidak Terpenuhi dari Pendapatan Usahatani Padi

\begin{tabular}{clc}
\hline No & \multicolumn{1}{c}{ Uraian } & $\begin{array}{c}\text { Jumlah } \\
\text { (Orang) }\end{array}$ \\
\hline 1. & $\begin{array}{l}\text { Responden yang konsumsi } \\
\text { rumah tangga tidak } \\
\text { terpenuhi oleh pendapatan }\end{array}$ & 28 \\
2. $\begin{array}{l}\text { usahatani padi } \\
\text { Responden yang konsumsi } \\
\text { rumah tangga terpenuhi } \\
\text { oleh pendapatan usahatani } \\
\text { padi }\end{array}$ & 43 \\
\hline & \\
\hline
\end{tabular}

Sumber: Data Primer diolah, 2017

Dari Tabel 22 dapat dilihat bahwa sebagian besar responden sudah dapat memenuhi konsumsi rumah tangga dengan pendapatan dari usaha tani padi. Untuk menambah pendapatan rumah tangga responden mencari pendapatan di luar usahatani padi. Responden yang total pendapatan rumah tangganya dapat dan tidak dapat memenuhi konsumsi rumah tangga tani sesudah adanya tambahan pendapatan di luar usahatani dapat dilihat pada tabel berikut.

Tabel 23. Konsumsi Bulanan per Rumah Tangga

\begin{tabular}{llc}
\multicolumn{2}{c}{ Tani dari Pendapatan Usahatani Padi } \\
\hline No & \multicolumn{1}{c}{ Uraian } & $\begin{array}{l}\text { Jumlah } \\
\text { (Orang) }\end{array}$ \\
\hline \multicolumn{1}{c}{$\begin{array}{l}\text { Responden yang konsumsi } \\
\text { rumah tangga tidak } \\
\text { terpenuhi oleh pendapatan } \\
\text { total rumah tangga } \\
\begin{array}{l}\text { Responden yang konsumsi } \\
\text { rumah tangga terpenuhi } \\
\text { oleh pendapatan total }\end{array}\end{array}$} \\
$\begin{array}{ll}\text { rumah tangga } \\
\text { Total }\end{array}$ \\
\hline
\end{tabular}

Sumber: Data Primer diolah, 2017
Dari Tabel 23 dapat dilihat bahwa setelah ditambah dengan pendapatan di luar usahatani padi sebagian besar yaitu sebanyak 62 responden dapat memenuhi kebutuhan hidup rumah tangganya. Sedangkan 9 responden tidak dapat memenuhi kebutuhan hidupnya dalam kenyataannya mereka masih dapat memenuhi kebutuhan hidupnya karena responden tidak memperhitungkan biaya tenaga kerja dalam keluarga sehingga mereka dapat memenuhi kebutuhan hidupnya.

Hasil penelitian ini sesuai dengan penelitian Ginting, Salmiah dan Jufri (2015). yang mengatakan bahwa rata-rata total pendapatan keluarga petani di Desa Tangga Batu lebih besar yaitu sebesar Rp16.727.573/ Tahun/KK dibandingkan dengan biaya yang harus dikeluarkan untuk konsumsi pangan yaitu sebesar Rp10.266.533/Tahun/KK

\section{Analisis Kebutuhan Hidup Layak (KHL)}

Analisis kebutuhan hidup layak dilakukan untuk mengetahui apakah pendapatan yang diperoleh responden dari usahatani padi sudah cukup untuk memenuhi standar kebutuhan hidup layak atau belum. Pendapatan yang diperoleh responden dari usahatani padi dibandingkan dengan standar kebutuhan hidup layak di Kabupaten Banyumas pada tahun 2016 yaitu sebesar Rp1.336.821,00 per bulan. Bila ratio menunjukkan angka $<1$ maka pendapatan rumah tangga tani dikatakan tidak mencukupi kebutuhan hidup rumah tangga tani, sedangkan jika ratio menunjukkan angka $\geq 1$ maka pendapatan rumah tangga tani mencukupi kebutuhan hidup rumah tangga tani. Dalam penelitian ini kelayakan hidup rumah tangga tani dihitung dari pendapatan rumah tangga tani dibagi jumlah tanggungan keluarga, hal ini dikarenakan untuk mendapatkan jumlah pendapatan perkapita. Kelayakan hidup rumah tangga tani dari pendapatan usahatani padi dapat dilihat pada tabel berikut. 
Tabel 24. Tingkat Kelayakan Hidup Rumah Tangga Tani dari Pendapatan Usahatani Padi

\begin{tabular}{cccc}
\hline No & $\begin{array}{c}\text { Kelayakan } \\
\text { Hidup Rumah } \\
\text { Tangga Tani } \\
(0-1)\end{array}$ & $\begin{array}{c}\text { Pendapatan } \\
\text { Usahatani } \\
\text { Padi (Rp) }\end{array}$ & $\begin{array}{c}\text { Jumlah } \\
\text { Responden } \\
\text { (Orang) }\end{array}$ \\
\hline 1. & $0,06-0,48$ & $\begin{array}{c}343.750- \\
2.635 .000\end{array}$ & 47 \\
& & $\begin{array}{l}2.115 .000- \\
2 .\end{array}$ & $\begin{array}{l}3.812 .500 \\
2.745 .000-\end{array}$ \\
3. & $>0,49-0,99$ & 16 \\
\hline & & 5.538 .750 & 71 \\
\hline
\end{tabular}

Tabel 25. Tingkat Kelayakan Hidup Rumah Tangga Tani dari Pendapatan Total Rumah Tangga

\begin{tabular}{lccc}
\hline No & $\begin{array}{c}\text { Kelayakan } \\
\text { Hidup Rumah } \\
\text { Tangga Tani } \\
(0-1)\end{array}$ & $\begin{array}{c}\text { Pendapatan } \\
\text { Usahatani } \\
\text { Padi (Rp) }\end{array}$ & $\begin{array}{c}\text { Jumlah } \\
\text { Responden } \\
\text { (Orang) }\end{array}$ \\
\hline 1. & $0,06-0,48$ & $\begin{array}{l}505.000- \\
2.740 .000\end{array}$ & 21 \\
2. & $>0,49-0,99$ & $\begin{array}{l}1.467 .500- \\
4.632 .500\end{array}$ & 34 \\
3. & $>1.00$ & $1.660 .000-$ & 16 \\
\hline & Jumlah & & 71 \\
\hline
\end{tabular}

Sumber: Data Primer diolah, 2017

Tabel 24 menunjukkan bahwa sebagian besar responden memiliki nilai kelayakan hidup rumah tangga $<1$. Itu artinya sebagian besar responden tinggal dibawah standar hidup. Rendahnya pendapatan usahatani padi yang tidak dapat mencukupi kebutuhan hidup layak membuat responden mencari pendapatan diluar sektor pertanian. Kelayakan hidup rumah tangga tani dari pendapatan total rumah tangga tani dapat dilihat pada tabel 25 yang menunjukkan bahwa dengan adanya tambahan pendapatan di luar usahatani padi angka kebutuhan hidup layak menjadi meningkat. Sebelum adanya pendapatan di luar usahatani padi, jumlah responden yang memenuhi standar kebutuhan hidup layak (KHL $>1$ ) terdapat 8 responden. Sedangkan dengan adanya tambahan pendapatan di luar usahatani padi, responden yang memenuhi standar KHL meningkat menjadi 16 responden.

\section{KESIMPULAN}

Berdasarkan hasil analisis data dan pembahasan yang telah dilakukan dalam penelitian ini, maka dapat disimpulkan beberapa hal sebagai berikut. Rata-rata pendapatan yang diperoleh responden di Desa Sambeng Kulon lebih besar dari biaya total untuk usahatani padi, sehingga pendapatan dari usahatani ini dikatakan menguntungkan. Besarnya keuntungan yang diperoleh responden yang memiliki luas lahan $>0,5 \mathrm{Ha}$ lebih besar dibandingkan dengan responden yang memiliki luas lahan $\leq 0,5 \mathrm{Ha}$. Nilai $\mathrm{R} / \mathrm{C}$ responden yang memiliki luas lahan $\leq 0,5 \mathrm{Ha}$ adalah 2,58 dan $>0,5 \mathrm{Ha}$ adalah 2,68.

Rata-rata kontribusi pendapatan usahatani padi terhadap pendapatan rumah tangga dari responden yang memiliki luas lahan $\leq 0,5$ hektar sebesar 54,96 persen sedangkan responden yang memiliki luas lahan $>0,5$ hektar memiliki kontribusi sebesar 77,43 persen.

Rata-rata pendapatan usahatani padi yang diperoleh responden sebesar Rp1.624.961,00, pendapatan dari usahatani tersebut sudah mencukupi untuk memenuhi konsumsi rumah tangga tani yang rata-rata sebesar Rp1.379.441,00. Rata-rata pendapatan yang diperoleh rumah tangga tani dari usahatani padi sebesar Rp1.624.961 sedangkan standar KHL di Kabupaten Banyumas pada tahun 2016 sebesar Rp1.336.821,00 perkapita perbulan. Sebagian besar rumah tangga tani tidak dapat memenuhi kebutuhan standar KHL.

Berdasarkan kesimpulan diatas, maka implikasi yang dapat disampaikan dalam penelitian ini adalah sebagai berikut. Secara keseluruhan usahatani padi sudah efisien dan memberikan keuntungan, responden diharapkan dapat mempertahankan tingkat efisiensi tersebut.

Kontribusi pendapatan usahatani padi yang diperoleh responden dengan kepemilikan lahan $\leq 0,5$ Ha lebih rendah sehingga diharapkan dapat meningkatkan luas lahannya, atau pengetahuan dan keterampilannya untuk terus meningkatkan produktivitas dan meningkatkan kualitas dari padi guna menaikkan harga jual.

Rata-rata pendapatan yang diperoleh responden sudah mencukupi untuk memenuhi kebutuhan hidup rumah tangga, namun responden diharapkan dapat terus meningkatkan pendapatan dari usahatani padi agar dapat menabung.

Sebagian besar pendapatan yang diperoleh responden dari usahatani padi masih berada di bawah standar kebutuhan hidup layak. Diharapkan responden dapat meningkatkan lagi pendapatan dari usahatani padi atau mencari penghasilan lebih banyak lagi di luar usahatani 
padi sehingga pendapatan yang diperoleh dapat mencukupi standar kebutuhan hidup layak perkapita.

\section{DAFTAR PUSTAKA}

Akbar \& Usman. (2009). Metode Penelitian Sosial. Jakarta: Bumi Aksara

Algifari. 2003. Statistika Induktif untuk Ekonomi dan Bisnis. AMYKPN. Yogyakarta.

Anton, Gapri M dan Marhawati. 2016. Kontribusi Usahatani Padi Sawah Terhadap Pendapatan Usahatani Keluarga di Desa Ogoamas II Kecamatan Sojol Utara Kabupaten Donggala. Jurnal Agrotekbis. Vol. 4 No. 1. Hal. 106 - 112.

Badan Pusat Statistika Indonesia. 2016.

Badan Pusat Statistika Provinsi Jawa Tengah. 2013.

Badan Pusat Statistika Provinsi Jawa Tengah. 2016.

Bappenas, 2013. Analisis Nilai Tukar Petani (NTP) Sebagai Bahan Penyusunan RPJMN Tahun 2015-2019. Kementrian Perencanaan Pembangunan Nasional. Jakarta.

Bappenas, 2013. Rencana Pembangunan Jangka Menengah Nasional (RPJMN) Bidang Pangan dan Pertanian2015 -2019. Kementrian Perencanaan Pembangunan Nasional. Jakarta.

Hendayana, R. 2001. Analisis Faktor-Faktor Yang Mempengaruhi Nilai Tukar Petani. Pusat Penelitian dan Pengembangan Sosial Ekonomi Pertanian. Badan Penelitian dan Pengembangan Pertanian. Bogor.

Kementrian Perencanaan Pembangunan. 2013. Analisis Nilai Tukar Petani Sebagai Bahan Penyusunan RPJMN Tahun 2015-2019. Jakarta Pusat

Kementerian Pertanian. 2015. Rencana Strategis Kementerian Pertanian Tahun 2015 2019.

Mentri Tenaga Kerja dan Transmigrasi. 2013. Komponen dan Pelaksanaan Tahap Pencapaian Kebutuhan Hidup Layak Nomor 13 Tahun 2013. Republik
Indonesia.

Mosher. 1987. Menggerakkan dan Membangun Pertanian. Yasguna, Jakarta

Monografi Desa Sambeng Kulon. 2016. Data Profil Desa Sambeng Kulon. Desa Sambeng Kulon.

Mulato, S, S. Widyotomo, Misnawi, Sahali dan E. Suharyanto. 2004. Petunjuk Teknis Pengolahan Produk Primer dan Sekunder Kakao. Bagian Proyek Penelitian dan Pengembangan Kopi dan Kkakao. Pusat Penelitian Kopi dan Kakao Indonesia. Jember.

Pancawati, Juwarin. 2012. Kontribusi Pendapatan Sektor Pertanian Terhadap Pendapatan Rumah Tangga Buruh Tani di Kelurahan Penancangan Kecamatan Cipocok Jaya Provinsi Banten. Jurnal Ilmu Pertanian dan Perikanan. Vol.1 No.1, Hal. 31-36.

Pratama, Putra. 2014. Analisis Pendapatan dan Kelayakan Usahatani Padi Sawah di Desa Sidondo 1 Kecamatan Sigi Biromaru Kbupaten Sigi. Jurnal Ilmu Pertanian. Vol.2 No. 1, Hal. 107-133.

Pusat Analisis Sosial Ekonomi dan Kebijakan Pertanian. 2007. Analisis Profil Petani dan Pertanian Indonesia. Departemen Pertanian

Soekartawi. 2002. Analisis Usahatani. UI Press. Jakarta

Soekartawi, 2003. Prinsip Ekonomi Pertanian. Rajawali Press. Jakarta

Statistik Indonesia. 2016. Luas Lahan Sawah Menurut Provinsi di Indonesia Tahun 2009 - 2014. Badan Pusat Statistika Indonesia.

Undang-undang No. 18. 2012. Undang-undang Nomor 18 Tahun 2012 Tentang Pangan. Republik Indonesia.

Ginting, Xaverius,; Salmiah; Jufri. 2015. Analisis Tingkat Pendapatan, Pola Konsumsi Dan Tingkat Penerimaan Petani Padi Sawah Varietas Lokal Ditinjau Dari Garis Kemiskinan (Studi Kasus : Desa Tangga Batu Ii, Kecamatan Parmaksian, Kabupaten Toba Samosir). Jurnal Pertanian dan Agribisnis Sosial 
Ekonomi. Vol. 21. No. 5 Hal. 12 - 30.

Yamane, Taro. 1967. Elementary Sampling

Theory. Englewood Chiffs. Prentice

Hall. 